\title{
The Impact of the Crisis on Economy and Labour Market, in the Southern European Countries. What about the "Mediterranean Model"?
}

\author{
By Anna Giulia Ingellis*
}

\begin{abstract}
This paper presents the first results of a research project developed in the last year. It aims at analysing and comparing the impact of the crisis on economy and labour market in the Southern European Countries (SECS). In the sociological and economic literature, these countries are considered similar up to the point of being included in a unique socio-economic model, named "Mediterranean". Starting from the evidence that the economic impact of the crisis in countries such as Greece, Italy, Portugal and Spain cause different changes in the labour market indicators, the analysis tries to test the theory of the existence of the "Mediterranean model" in the way in which the SECs reacted to the crisis. Data related both to the labour market and to national economic impact have been analysed. Eurostat was the principal data source. The analysis compares the main indicators before and after the crisis about the economic impact, the labour market changes, as well as convergences and divergences between the two. The results point out the existence of significant divergences among the SECs in the way they have been affected by the crisis. This awareness should lead the analysts to be cautious with the idea of the existing homogeneity of this area, above all at the time of designing public policies. The existence of a "Mediterranean model", as for the reaction to the crisis, is open to contention.
\end{abstract}

Keywords: Comparative study, Economic impact, Labour market impact, Mediterranean model, Unemployment.

\section{Introduction}

The recent long-lasting economic recession has produced diverse effects in different European countries. As the main statistics data make evident, one of the European areas with the worst economic impact is that of the Southern European Countries (SECs, starting from now).

Both in the European political debate and in the mass media representation of the downturn impact, Italy, Portugal, Greece and Spain are considered the countries with the worst situation up to the point of being called "PIGS", in a quite derogative sense. This generalized idea makes the elements they have in common, a negative impact of the crisis, more evident than the differences. The more obvious consequence of this homogeneous image has been to legitimate European Commission imposing those similar policies. The supposed common difficulties were used to justify uniformed interventions.

\footnotetext{
${ }^{*}$ Lecturer, University of Valencia, Spain.
} 
Nonetheless, actually they need similar policies? Actually the impact of the crisis was so parallel that similar measures need to be applied to overcome the recession? The principal aim of this paper is to describe both similarities and differences in the way these countries have reacted to the crisis as for economic and labour market issues. Furthermore, the objective was to prove or refuse the idea that, as for the crisis impact, it still makes sense speaking about the existence of a "Mediterranean model".

The text will be organized in 4 parts: in the first one the theoretical framework which founds the idea of the existence of a "Mediterranean model" in the economic and social organization of these countries will be presented. In the second one the economic impact of the crisis in the SECs, underlining differences and similarities will be described. The following part will be focused on the labour markets response to the downturn in a comparative perspective. Finally, economic and labour market impacts will be compared, highlighting convergences and divergences.

\section{The "Mediterranean Model" and its Theoretical Basis}

There is an extended scientific literature and studies about the similarities among SECs countries in a wide range of issues. The growing availability of data, about several aspects of social and economic dimensions at an international level, made possible an extensive range of comparative studies. The creation of the European Union and above all of a centralized statistic data gathering, throughout Eurostat, allows researchers to promote accurate multivariate analysis about diverse social and economic phenomena in the European Countries. We can classify the literature reviewed depending on the aspects the studies are focused on. The most interesting for our purpose are those related with welfare state and labour markets. Addressing SECs features, there are both, studies about European countries in general (Barbieri 2007, 2009, Esping-Andersen 1990, Esping-Andersen and Regini 2000, Molina and Ibañez 2013, Serrano Pascual 2007) and studies focused only on SECs countries (Andreotti et al. 2001, Baumeister and Sala 2015, Ferrera 1996, Guillén et al. 2016, King 2002, Maddaloni 2009, Moreno 2002, 2006, Rodhes 1997, Sapelli 1996).

In the first type of studies, the SECs are considered as belonging to the same cluster, because of the similarities among them and the divergences with the others countries. Starting from the first Esping-Andersen's study (1990) in which he underlines that "The welfare-state variations we find are not linearly distributed, but clustered by regime type" (Esping-Andersen 1990: 26), there are several cluster analysis confirming the belonging of the Southern European Countries to the same cluster. In the second type of studies the focus is specifically centered in the European countries of the Mediterranean area.

The most important aspects, in which the literature reviewed point out similarities among these countries, are those related with the welfare system, the labour market structure and its regulatory framework, and the economic 
structure. Starting from the well-known Esping-Andersen's typology about welfare capitalism (1990), SECs are considered similar regarding their welfare system. According to the author, they all belong to the conservative corporative model distinguished from the liberal and social democratic ones. In this model, social rights are attached to class and status and the system maintain these differences with quite inexistent redistributive policies. These welfare systems are founded on the traditional familyism and deeply influenced by the Church. The care services are centered on the family and the role of the state is subsidiary. The market presence in the care services is irrelevant. If, in this first formulation, the SECs are associated to the central European countries, in following studies they achieved an own autonomy as a specific social and economic model, the "Mediterranean model", exactly (Ferrera 1996, Rhodes 1997, Sapelli 1996). As pointed out by Maddaloni (2009: 79), this new wave of studies confirmed the welfare state structure similarities and extended them to a wider range of aspects such as: the predominant presence of micro and smallsized companies and a high rate of autonomous workers, a labour market structure based on a high level of gender, social class, educational level, and regional based segmentation, a pervasive power of a patronage system to distribute rights.

During the 90s, it became very common speaking of the "Mediterranean model" to describe the structural features of SECs' labour markets, referring above all to the segmentation by age, gender and class (Pugliese 1996).

As explored by Maddaloni (2009), this model seems to persist during the first decade of the 21 st century, till before the last crisis. In his work he argued that the SECs' labour markets arrive to the crisis with a structure which makes difficult to them to transform themselves in postindustrial labour markets, taking advantage of, for instance, the new services economy. Maddaloni's research underlines the idea that Southern Europe represents a peculiar reality in comparison with the rest of Europe, characterized by the relevant role of the family and the reproduction of inequalities in the labour market on a gender and social class base.

From a more institutional point of view, the rising relevance of the European active labour market policies has boosted comparative studies concerning the different national reforms. As for the political response to the financial crisis, facing the consequences in labour markets, Molina and Ibañez (2013: 133) presented the situation of Spain, Italy, Greece and Portugal under the label of "Mediterranean": again the SECs are assimilated. In this case they are considered similar in the way they try to reduce the impact of the crisis. Nonetheless, the authors actually seem to be aware that this is more a residual category, than a way to underline real common features, above all in labour market issues. In the detailed analysis carried out by Bosch et al. (2009), for each one of the SECs we find the peculiarities of the institutional change promoted during the transition to the post-industrial society. In this study the striking immobility of the Italian case, and, with more or less difficulties, the change to a neoliberal model of Greece and Spain are emphasized. 
Literature is not as homogeneous as it could appear at a first glance, Andreotti et al. (2001) since 2001 questioned the existence of a Southern European Model and the fragmentation of the Mediterranean welfare model, caused by the crisis, is explored in a recent study, too (Guillén et al. 2016). The crisis has made cuts and changes in welfare state compulsory and the national reforms have led SECs in varied directions.

As to the economic structure, the prevalence of micro small-sized companies and the presence of a similar distribution by branch are the more relevant common features of the SECs. As stated by Mulhern (1995: 83), "The Mediterranean countries (Italy, Spain, Greece, Portugal and the Southern France) have a greater preponderance of smaller firms than the generally wealthier Northern European countries. Denmark, Germany, France, and Britain, for example, have an average enterprises size over the double of that of Portugal, Spain, Italy and Greece". The predominance of low innovation intensity sectors and similar distribution by branch of the Gross Value Added are others of the indicators of similarities in SECs economic structures. (Sánchez 2009). The weakness of the entrepreneurial fabric is another feature they have in common.

As this review clearly evinces, there are several and relevant socioeconomic features which indicate similarities among SECs. The most obvious consequence of these common traits would have been a very similar reaction to the last downturn. The aim of this first step of this research has been exactly to ascertain if the predominance of the similarities that have characterized the reaction to this last crisis. The main questions have been: what about this similarity during the crisis? Have they reacted in a similar way? Can we talk about a "Mediterranean" reaction pattern? Is the similarity of the economic and social policies imposed to these countries (austerity and structural reforms) founded on substantial similarities in the impact of the crisis?

\section{Objective, Methodology and Data Source}

As exposed above, the general objective of this research was to study how the SECs reacted to the crisis as for both the economy and labour market. The socio-economic features, on which literature bases the idea of a "Mediterranean model", are closely and strictly related with the feature most affected by the crisis. The main research questions have been focused on the most affected features of each country by the recent downturn, distinguishing converging and diverging aspects.

In order to study the economic impact, we analysed the following aspects: how the Gross Domestic Product (GDP) reacted to the crisis? How did its components (export, import or final internal expenditures) change? Improving export, reducing? There has been an economic restructuration by branch? In which way the Gross Value Added changed (GVA) in each country? In which aspects the changes were more similar among these countries and in which more diverse? 
As for the labour markets: which ones have been more sensitive to the economic crisis effects? The active population increased or decreased in each country? What about the unemployment, the gender and age based segmentation? In which countries young people were more affected and in which less?

For this descriptive preliminary step, the methodology used has been a literature review and a secondary data analysis. 2006 has been considered the year before the crisis and 2013 the year in which the impact of the crisis is perfectly visible. In fact, that year shows the worst unemployment rate since the beginning of the crisis. Starting from 2014 a slow recovery started. The main data source was the Eurostat database. As for the indicators considered, it is important to underline that all the rate changes have been taken in account and not the rates in themselves, because the focus was on the reaction to the crisis (and the changes generated by the crisis) and not on the similarities and differences among the SECs before or after the crisis. The comparative analysis was focused on dynamic effect of the crisis and not on the comparison among SECs in a certain moment, before or after the crisis. The differences between the rates in the two key years have been considered the main indicators of the impact of the crisis.

\section{The Reactions at a First Glance}

The starting point of this research has been the evidence that the SECs' labour market (LM) had deeply different reactions to the crisis. As shown in the following table, the unemployment rate in Spain and Greece changed with a very different intensity from Italy and Portugal. In the first two countries its growth was significantly higher than in the second ones. The crisis destroyed much more jobs in Spain and Greece than in whatever one.

Table 1. Unemployment Percentage Rate Change

\begin{tabular}{|l|c|c|c|c|}
\hline & Italy & Spain & Greece & Portugal \\
\hline 2006 & 6.8 & 8.05 & 9 & 8.9 \\
\hline 2013 & 12.1 & 26.10 & 27.5 & 16.4 \\
\hline Rate Change & $\mathbf{5 . 3}$ & $\mathbf{1 8 . 0 5}$ & $\mathbf{1 8 . 5}$ & $\mathbf{7 . 5}$ \\
\hline
\end{tabular}

Source: Eurostat

Are these differences in the labour market strictly related with the seriousness of the economic downturn in each country? Comparing the rate changes of two key rates respectively of the labour market impact (unemployment) and of the economic impact (the GDP decrease), it is evident that they aren't strictly related (fig.1). The increase of the unemployment rate is not proportional to the GDP decrease rate variation, not at all leastwise. Eliminating any inflation influence, (throughout the use of the GDP decrease index 2010: 100), the absence of a correlation appears evident. As shown in Figure 1, the unemployment growth is not at all proportional to the GDP 
decrease. They are two opposite situations. On the one hand there are the countries in which the reduction of the production is more relevant than the employment destruction; it is the case, even if in different proportions, of Greece and Italy. On the other hand, there is Spain and Portugal where, on the opposite, the employment destruction is more significant than the production one. The case of Spain is really remarkable: a relevant rise of unemployment rate corresponds to a relatively low GDP decrease.

Figure 1. Unemployment and GDP Decrease - rate changes (2006-2013)

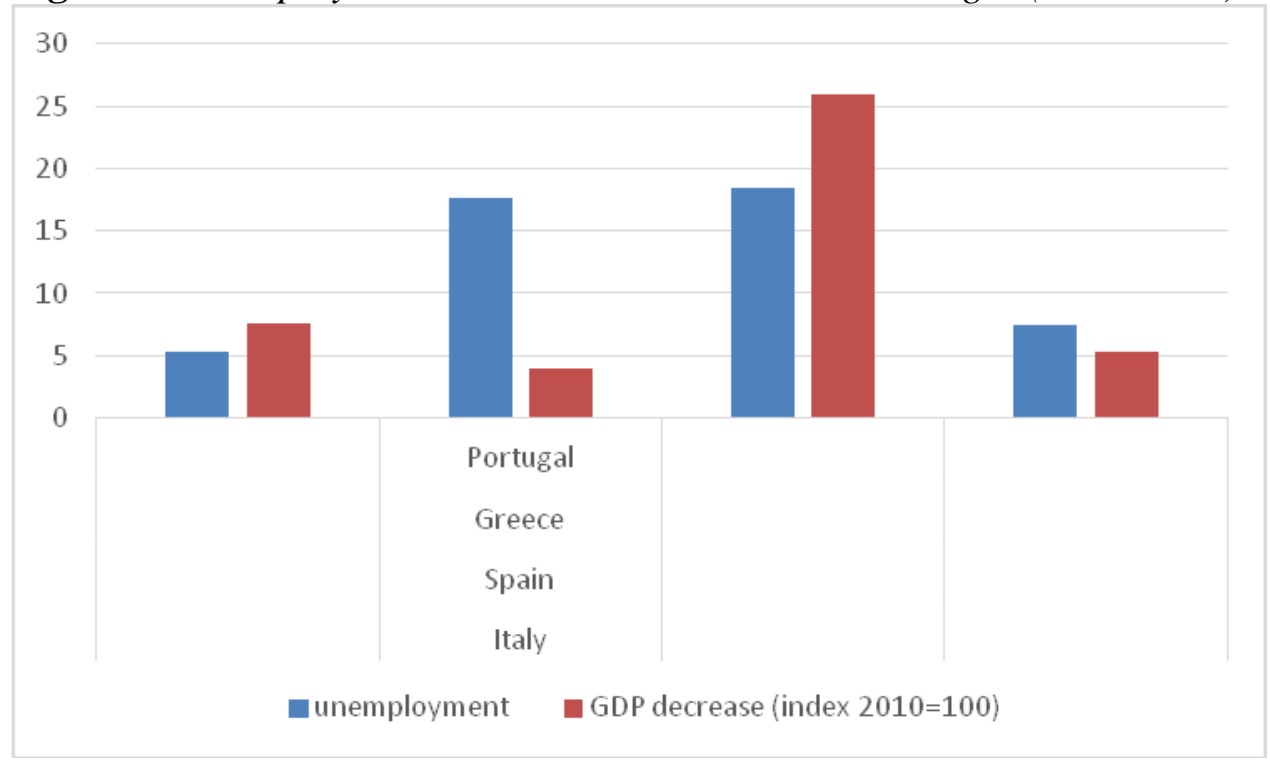

Source: Eurostat

The indicators considered above illustrate the great difference in the way production and labour has been destroyed because of the crisis. Even if, except in the case of Spain, there is a proportion between economic impact and LM impact -the more economy deteriorates, the more occupation decreasesemployment destruction is much more intense. Carrying on the comparative analysis among these 4 countries, relevant differences are evident: The Greek economic situation appears disastrous and more onerous than in the others countries. Spain shows a peculiarity regarding the price paid by the labour factor of production, because of the crisis. On the opposite, the labour market in Italy seems to be less sensitive to the economic crisis. At this first glance the remarkable differences among the SECs don't suggest that there has been a "Mediterranean" way to react to the crisis as for the economy and labour market.

To analyse in a deeper way these differences. 2 areas have been explored: firstly, the impact of the crisis on the economy and then the impact on the labour market. In the following two paragraphs the main results will be illustrated. 


\section{Economic Impact of the Crisis}

Regarding the economic impact of the crisis, the variables considered were the GDP and its components and the GVA distribution by sector.

Figure 2. GDP Decrease - rate Changes (2006-2013)

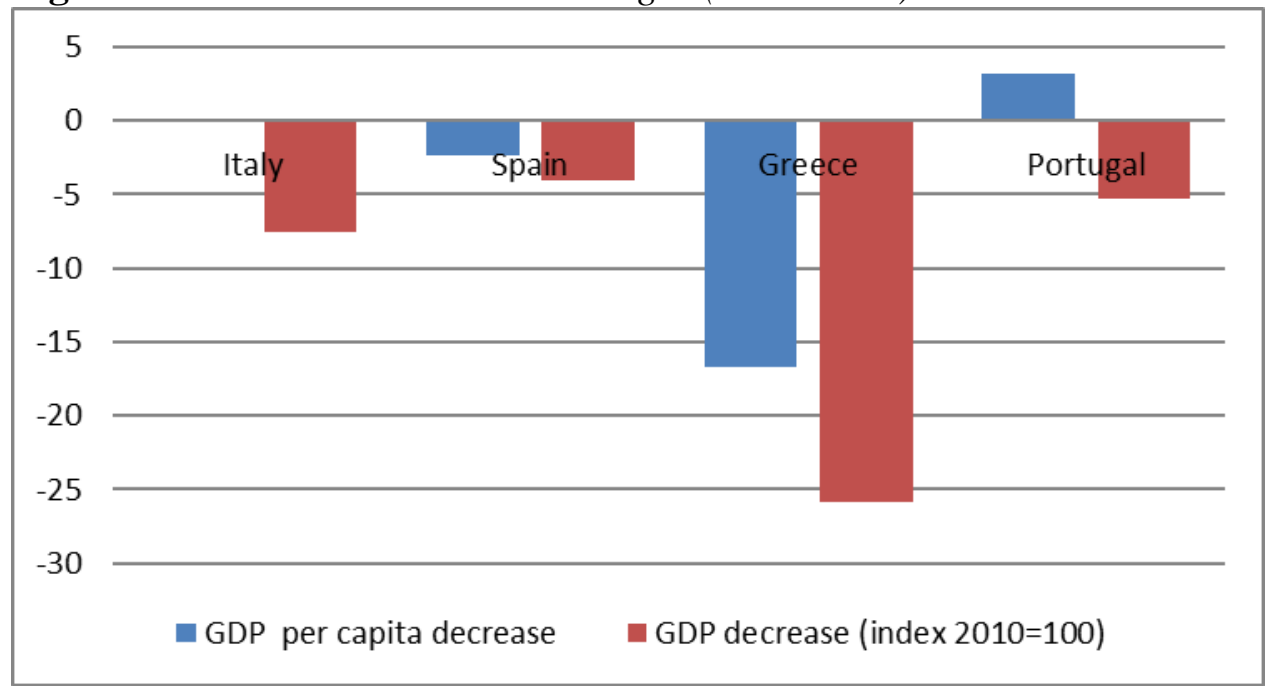

Source: Eurostat.

The Figure 2 represents that, in terms of GDP changes, depending on the crisis, the Greek situation is the worst, above all in terms of the GDP per capita: not only the GDP change was negative, more than in the other countries, but considering the "per capita" rate, the distribution among the population of the GDP, the situation appears even more grave. Italian GDP decrease was weak and its per capita variation was null. Even though the economic impact was negative in all these countries, it can't be asserted that the main factors variations have been similar in all of them.

First of all because the intensity of the GDP decrease was different and secondly because its distribution on population was different too: in Portugal there has been a growth of the GDP per capita, in spite of a general GDP decrease, and in Italy the GDP decrease had no effect at a per capita level. Definitively the Greek and Portuguese reactions in terms of GDP or GDP per capita decrease, for example, can't be assimilated.

Deepening the analysis, if we consider the several components of GDP, two are the most striking points (see Figure 3): The Spanish and Portuguese ability to significantly improve their export and the downfall of internal consumption in Greece and in Spain, even if in a less relevant way in the last one. 
Figure 3. GDP and its Main Components, Rate Changes (2006-2013)

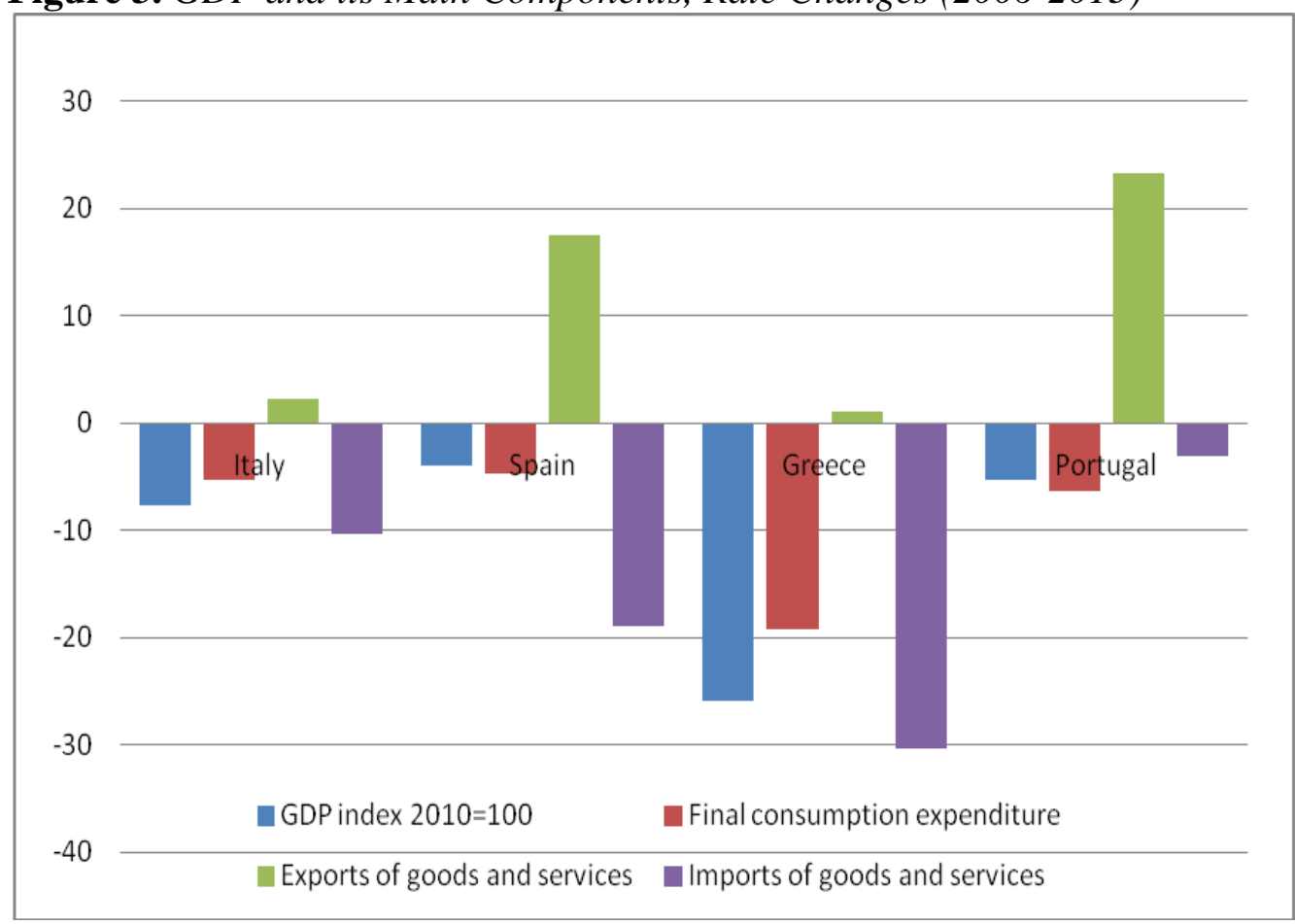

Source: Eurostat.

In order to observe the impact of the crisis on the productive structure, the Gross Value Added distribution by branch has been analysed. The higher weight of construction and its severe downfall characterizes the two countries with the worst situation, Spain and Greece. In these two countries the construction was as relevant as the manufacturing sector before the crisis. The Figure 4 shows that the construction sector in Greece has been almost totally destroyed (passing from 8.9\% to 1.8\%) during the crisis and in Spain its relevance was halved. In Spain the services sector absorbed the downfall of the construction branch $(+8.2 \%)$. In Portugal construction lost relevance too, but in a less measure $(-3 \%)$ and in Italy it almost didn't change $(-0.7 \%)$. Nonetheless, while in Portugal it means a transfer from construction to services, remaining almost unchanged manufacturing and industry, in Italy a transfer of GVA production from manufacturing $(-2.5 \%)$ and industry $(-1.8 \%)$ to services $(+5.4 \%)$. has been registered. Manufacturing and industry slightly improved their relevance in Portugal and in Greece. In Greece, the services sector grew at the same extent as in Italy $(+5.2 \%)$. 
Figure 4. GVA Distribution by Branch (2006-2013)

industry manufacturing construction $\square$ services

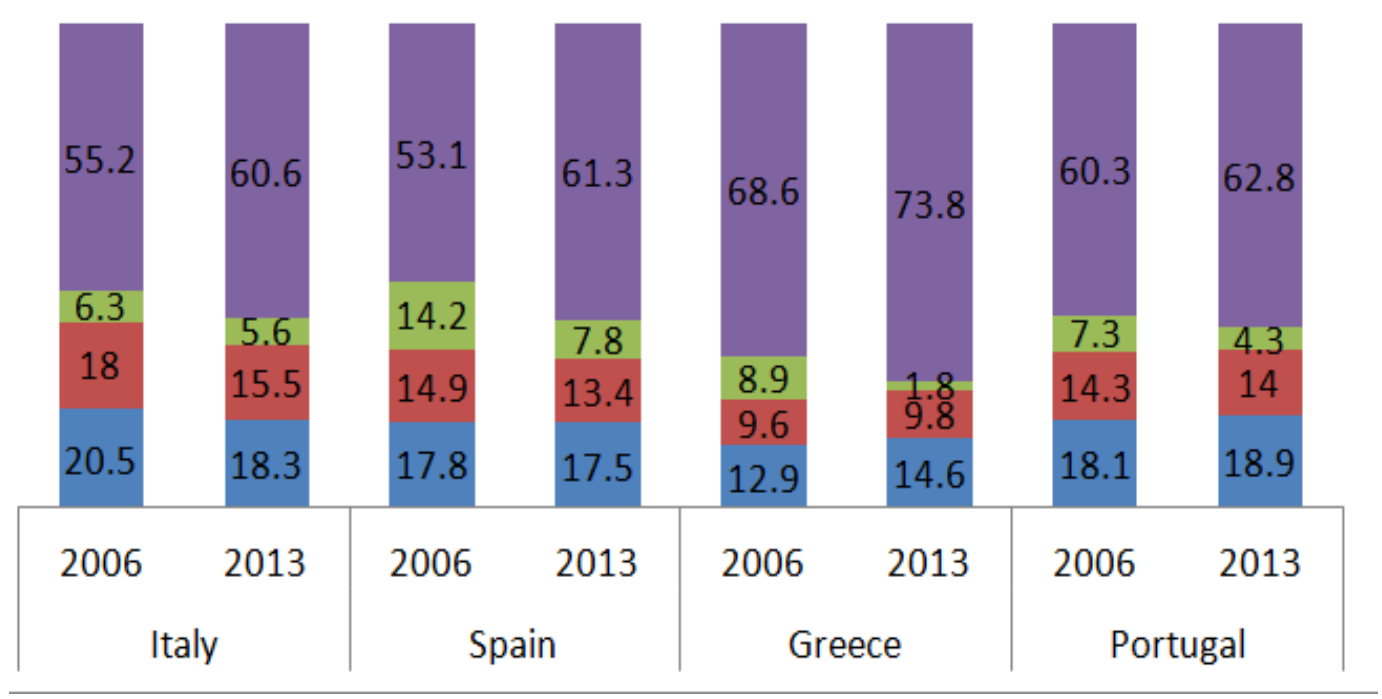

Source: Eurostat.

The crisis has definitively produced changes in the productive structure of these countries but not in the same way. The only thing they have in common is the growing weight of services. The role of this sector, during the crisis, could be explained in two different ways: the first one is that the services branch seems to have worked as a "shock absorber" in all the countries, even if with a different intensity. The other hypothesis is that this crisis has put forward the process of transformation of the industrial society toward a services society in the SECs. The future will solve this doubt: is it a temporary change or a symptom of a more structural transformation?

\section{Labour Market Impact}

The recent downturn is known for its grave consequences in the labour market. 
Vol. 4, No. $3 \quad$ Ingellis: The Impact of the Crisis on Economy and Labour Market...

Figure 5. Main Labour Market Indicators Rate Changes (2006-2013)

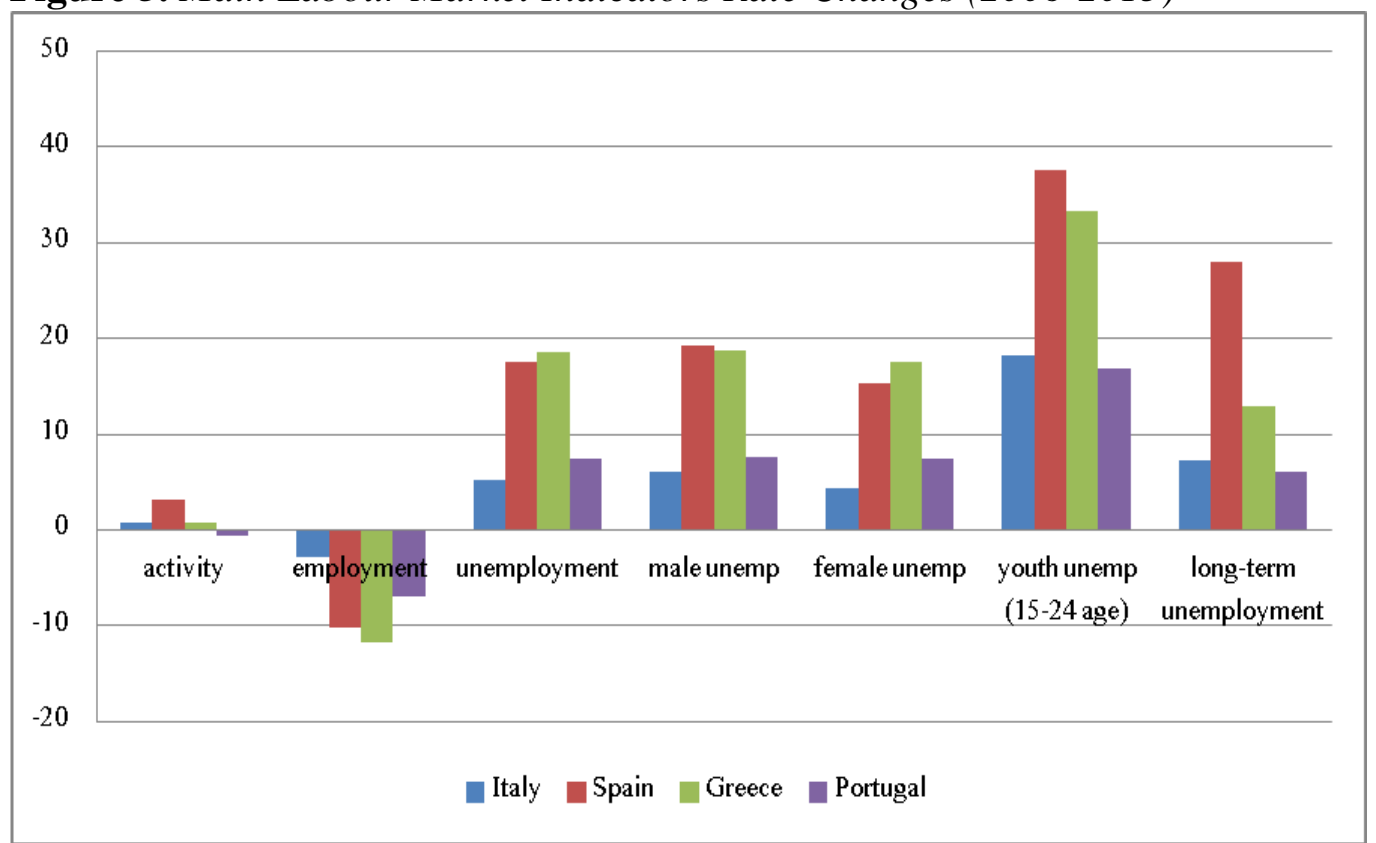

Source: Eurostat.

The unemployment growth in Spain and Greece is noteworthy and has produced a relevant social impact in terms of inequality and poverty (Gutierrez Palacios 2014, OCDE 2011). In Spain the youth unemployment rate and above all the growth of the long-term unemployment rate are particularly relevant. The last one datum is apparently striking: long-term unemployment grew more than doubled the initial rate of $21.7 \%$ (+ 28 points). Nonetheless it is not particularly surprising, taking in account that, before the crisis, the Spanish long-term unemployment was the lowest one. Furthermore, in Spain this crisis seems to have affected men more than women. Young people indeed have been the most affected: in the SECs they actually could barely enter the labour market.

Looking at the rate changes that occurred because of the crisis (comparing the "change" columns in the Table 2), it is evident and striking that the Italian ones are the less relevant changes. 
Table 2. The Impact of the Crisis on Labour Markets

\begin{tabular}{|c|c|c|c|c|c|c|c|c|c|c|c|c|}
\hline \multirow[b]{2}{*}{ Rates } & \multicolumn{3}{|c|}{ Italy } & \multicolumn{3}{|c|}{ Spain } & \multicolumn{3}{|c|}{ Greece } & \multicolumn{3}{|c|}{ Portugal } \\
\hline & 2006 & 2013 & Change & 2006 & 2013 & Change & 2006 & 2013 & Change & 2006 & 2013 & Change \\
\hline Activity & 62.6 & 63.4 & 0.8 & 71.1 & 74.3 & 3.2 & 66.7 & 67.5 & 0.8 & 73.6 & 73 & -0.6 \\
\hline Employment & 58.3 & 55.5 & -2.8 & 65 & 54.8 & -10.2 & 60.6 & 48.8 & -11.8 & 67.6 & 60.6 & -7 \\
\hline Self Employment & 26.5 & 27.7 & 1.2 & 14.1 & 13.7 & -0.4 & 35.1 & 33.7 & -1.4 & 18.2 & 16.6 & -1.6 \\
\hline Salaried Employment & 73.5 & 72.3 & -1.2 & 85.9 & 86.3 & 0.4 & 64.9 & 66.3 & 1.4 & 81.8 & 83.4 & 1.6 \\
\hline Part Time & 13.3 & 17.9 & 4.6 & 11.8 & 15.8 & 4 & 5.8 & 8.5 & 2.7 & 11.5 & 14.3 & 2.8 \\
\hline Temporary & 13.1 & 13.2 & 0.1 & 34 & 23.1 & -10.9 & 10.8 & 10.1 & -0.7 & 20.4 & 21.4 & 1 \\
\hline Unemployment & 6.8 & 12.1 & 5.3 & 8.5 & 26.1 & 17.6 & 9 & 27.5 & 18.5 & 8.9 & 16.4 & 7.5 \\
\hline Male Unemp & 5.4 & 11.5 & 6.1 & 6.4 & 25.6 & 19.2 & 5.7 & 24.5 & 18.8 & 8.6 & 16.3 & 7.7 \\
\hline Female Unemp & 8.8 & 13.1 & 4.3 & 11.4 & 26.7 & 15.3 & 13.8 & 31.4 & 17.6 & 9.1 & 16.6 & 7.5 \\
\hline $\begin{array}{l}\text { Youth Unemp (15-24 } \\
\text { Age) }\end{array}$ & 21.8 & 40 & 18.2 & 17.9 & 55.5 & 37.6 & 25 & 58.3 & 33.3 & 21.2 & 38.1 & 16.9 \\
\hline Male & 19.2 & 39 & 19.8 & 15 & 56.2 & 41.2 & 17.6 & 53.8 & 36.2 & 19.9 & 36.7 & 16.8 \\
\hline Female & 25.4 & 41.5 & 16.1 & 21.5 & 54.6 & 33.1 & 34.2 & 63.8 & 29.6 & 22.8 & 39.7 & 16.9 \\
\hline $\begin{array}{l}\text { Long-Term } \\
\text { Unemployment }\end{array}$ & 49.6 & 56.9 & 7.3 & 21.7 & 49.7 & 28 & 54.1 & 67.1 & 13 & 50.4 & 56.4 & 6 \\
\hline
\end{tabular}

Source: Eurostat 
As deeply analysed in previous research focused exclusively on Italy and Spain (Ingellis and Calvo 2015), all the Italian rate changes are lower than the ones of other countries. On the contrary, the highest rate changes are those of Spain. The Spanish labour market was the one in which the most relevant changes occurred. The most noteworthy are: 1 . the fall of the temporary rate: because the first who were made redundant were the temporary workers; 2 . the growth of youth unemployment: young people were the most affected by the crisis in terms of occupation; 3. the rise of the activity rate: more people, especially women, enter in the labour market. These features of the Spanish labour market are not recent. They characterize Spain since the labour market reforms, during the 80s, which introduced a high rate of flexibility (Dolado et al. 2002). Greece has a similar situation as for unemployment growth (youth, male and female ones), but not for the activity rate rise and the fall of temporary rate which, being already low before the crisis, did not change. Portugal presents a situation, in terms of changes due to the crisis, similar to Italy even if the unemployment rise is 2 points more relevant. About Portugal it is interesting to highlight that the segmentation, on gender base, is less relevant: the unemployment rates and its changes are similar for men and women. The youth unemployment rate, in comparison with the other 3 countries, is the one which less arise both for male or female youth people.

\section{Economic and Labour Market Impact in Comparison: Convergences and Divergences}

In this paragraph, in order to make more evident the relation between the economic and labour market impact, the main changes pointed out till now will be resumed, throughout the following comparative table. Furthermore, it will be underlined in which cases the labour market reaction is coherent with economic downturn intensity or, on the opposite; the labour market impact strength seems not to be justified by the economic recession. The national contexts analysed are presented from the most affected by the crisis to the least. 
Table 3. Economy and Labour Market: the Impact of the Crisis on the SECs

\begin{tabular}{|c|c|c|}
\hline Countries & Economic impact & Impact on labour market \\
\hline Greece & $\begin{array}{l}\text { The worst economic situation. } \\
\text { Intense recession with the worst } \\
\text { consequences on the population. } \\
\text { GDP per capita. import of goods } \\
\text { and services and the final } \\
\text { consumption are the indicators } \\
\text { with the worst values. Greek } \\
\text { economy seems to be reduced to } \\
\text { an asphyxiated internal market } \\
\text { based on services. }\end{array}$ & $\begin{array}{l}\text { The impact on labour market is as grave as } \\
\text { the economic one. The employment } \\
\text { destruction has been relevant and has } \\
\text { affected young people above all. }\end{array}$ \\
\hline Spain & $\begin{array}{l}\text { Spain presents the second worst } \\
\text { situation. } \\
\text { The GDP decrease with a less } \\
\text { intense impact on population } \\
\text { (The GDP per capita and final } \\
\text { consumption less reduced than } \\
\text { overall the GDP). The downturn } \\
\text { impact seems reduced thanks to } \\
\text { the export. A more open and } \\
\text { dynamic market seems to } \\
\text { characterize the Spanish economic } \\
\text { situation. }\end{array}$ & $\begin{array}{l}\text { The worst labour market impact of the } \\
\text { crisis. The companies use labour factor } \\
\text { adjustment to survive the crisis: part-time } \\
\text { contracts grew and mainly temporary } \\
\text { workers were made redundant. An increase } \\
\text { of activity rate indicates the need for more } \\
\text { people to enter the labour market, women } \\
\text { above all. The long-term unemployment } \\
\text { increase indicates a relevant change: a } \\
\text { previous dynamic labour market became } \\
\text { much more static. }\end{array}$ \\
\hline Italy & $\begin{array}{l}\text { In Italy the GDP decrease comes } \\
\text { after the long-lasting trend of } \\
\text { stagnation during the last } 20 \text { years. } \\
\text { The GDP decrease is not as } \\
\text { relevant as in Greece and in } \\
\text { Spain and doesn't have } \\
\text { repercussions almost at all on the } \\
\text { population (GDP per capita) }\end{array}$ & $\begin{array}{l}\text { The labour market in Italy has not suffered } \\
\text { a relevant impact because of the recent } \\
\text { crisis. All the changes have been less } \\
\text { relevant than in the other countries. Even if } \\
\text { they come to make graver a difficult } \\
\text { previous situation. }\end{array}$ \\
\hline Portugal & $\begin{array}{l}\text { Portugal presents a situation } \\
\text { similar to Spain but with a reduced } \\
\text { impact on imports and the best } \\
\text { performance in terms of exports. } \\
\text { Its productive structure change } \\
\text { less than in all the other } 3 \\
\text { countries }\end{array}$ & $\begin{array}{l}\text { The labour market reaction in Portugal is } \\
\text { really similar to the Italian one. } \\
\text { Nonetheless. In a qualitative perspective it } \\
\text { is remarkable that segmentation on gender } \\
\text { or age base is less relevant: the } \\
\text { unemployment rates and changes are } \\
\text { similar for men and women. The youth } \\
\text { unemployment rate is the one which rises } \\
\text { less both for male or female youth people. }\end{array}$ \\
\hline
\end{tabular}

Comparing the situation in SECs, it seems that there have been two kinds of reactions: a deeper and more striking one which characterizes Greece and Spain and a less relevant one for Portugal and Italy. Nonetheless, we registered many differences even in these two subgroups.

In Spain the GDP decrease is quite less relevant than in Greece. In addition, the employment destruction was more intense in Spain than in Greece. Between Portugal and Italy, we founded out similarities but significant differences too. The export relevance in Portugal and the more profound transformation of the productive structure in Italy, make the two economic situations different. Furthermore, the Italian and the Portuguese labour markets are similar as for the relevance of the indicators changes, but they present 
relevant differences as for gender and age based segmentation, since the Portugal situation is more positive than the Italian one.

Regarding the coherence between the economic and labour market impact several differences are evident, too. In the Greek labour market, the crisis seems to correspond and reflect the economic situation. The worst economic performance rebounds into the worst LM reaction. On the contrary in Spain we found out that a less relevant economic impact corresponds to the worst labour market impact of the SECs. The companies seem to use labour factor adjustment to survive the crisis: part-time contracts grew and mainly temporary workers were expelled. Portugal presents an intermediate level of crisis impact and a more balanced situation between the economic and labour market crisis.

Finally, Italy was the country with the less relevant impact of the crisis, among the SECs.

The permanent crisis Italy has lived in the last 20 years (Damioli 2012) seems to allow it a less relevant reaction to the recent temporary crisis (Molina and Ibáñez 2013). The resistance to structural changes paradoxically (or not?) makes Italy more resistant to disastrous changes due to the recent downturn.

\section{Conclusions}

The comparison carried out till now, makes evident that in two of the social structures most affected by the crisis (economy and labour market) the similarities among the SECs are not as obvious and evident as it seems to suggest the idea of a "Mediterranean model", raised in the economic and sociologic literature during the $90 \mathrm{~s}$. The impact of the crisis has revealed significant differences among these countries: a different level of segmentation, different distributional changes, and different restructuration of the productive structure by branch. The labour markets didn't react in the same way: The Italian LM seems to be characterized by less elasticity and Spain, on the contrary, presents a striking sensitivity to the economic cycles, above all in its negative phase. Greece's situation is strikingly grave and Portugal performs a more equilibrate pattern. It makes the uniformity of the economic policies known with the name of "austerity" less obvious and inevitable than the common definition of SECs as PIGS suggests.

Probably the crisis introduced elements of fragmentation in this European area, but it is not unlike that the national labour market reforms carried out in each country to face the globalization and the transition to a post-industrial society, took a great part in generating these differences in the sensitivity of the LM to the economic recession. This research has been a first descriptive attempt to focus on differences among SECs, when the mainstream literature in general puts its attention on the converging point.

This first exploratory comparison suggests leastways two new research lines. On the one hand the analysis of the economic and LM structural features in the SECs, prior to the crisis, searching for explanatory factors for these different reactions. On the other hand, the role played by the social and labour 
market policies to face the crisis could help to describe a more complex scenario.

\section{Acknowledgement}

The idea to write this paper was encouraged by Domenico Maddaloni (University of Salerno) because of our common interest in Southern European Country issues. I thank him for his helpful comments and his backing.

\section{References}

Andreotti A, Garcia SM, Gomez A, Hespanha P, Kazepov Y, Mingione E (2001) Does a Southern European Model exist? Journal of European Area Studies 9(1).

Barbieri P (2009) Flexible Employment and Inequality in Europe. European Sociological review 6: 621-628.

Barbieri P (2007) Atypical employment and welfare regimes. Policy Papers. Equalsoc. Economic Change. Quality of life\& Social Cohesion 1: 1-23.

Baumeister M, Sala R (Eds) (2015) Southern Europe? Italy, Spain, Portugal and Greece from the 1950s until the present day. Chicago. Campus Verlag.

Bosch G, Lehndorff S, Rubery J (2009) European employment models in flux. A comparison of institutional change in nine European countries. Basingstoke: Palgrave MacMillan.

Damioli G (2012) Labour market in times of crisis. The Italian situation in the EU context. 2007-2011. Conference proceeding "Crisis. empleo y cambio social en el Sur de Europa" (March.2012). Universitat Autònoma de Barcelona.

Dolado JJ, García-Serrano C, Jimeno JF (2002) Drawing Lessons from the boom of temporary jobs in Spain. The Economic Journal 112: 270-295.

Esping-Andersen G (1990) The three worlds of welfare capitalism. Cambridge: Polity Press.

Esping-Andersen G, Regini M (2000) Why deregulate Labour markets. Oxford. Oxford University Press.

Ferrera M (1996) The "southern model" of welfare in social Europe. Journal of European Social Policy 6: 17-37.

Guillén AM. González-Begega S, Luque D (2016) Austeridad y ajustes sociales en el Sur de Europa. La fragmentación del modelo de bienestar Mediterráneo [Austerity and social adjustment in Southern Europe. The fragmentation of the Mediterranean welfare model]. Revista Española de Sociología 25(2): 261-272.

Gutierrez Palacios R (2014) Welfare performance in Southern Europe: employment crisis and poverty risk. South European Society and Politics 19(3): 317-392.

King MC (2002) Strong families or patriarchal economies? Southern European labour markets and welfare in comparative perspective. European University Institute. Robert Schuman Centre for Advanced Studies. Mediterranean Program Series. Working Paper. n. 14. Retrieved from http://www.iue.it

Ingellis AG, Calvo R (2015) Desempleo y crisis económica. Los casos de España e Italia [Unemployment and economic crisis. The cases of Spain and Italy]. Sociología del trabajo. nueva época. 84. 7-31. 
Vol. 4, No. $3 \quad$ Ingellis: The Impact of the Crisis on Economy and Labour Market...

Maddaloni D (2009) Il modello sudeuropeo di mercato del lavoro nel contesto continentale: un'indagine esplorativa [The South East European labor market model in a continental context: an exploratory investigation]. Economia \& Lavoro XLIII: 77-93.

Mulhern A (1995) The SME sector in Europe: a broad perspective. Journal of Small Business Management 33(3): 83-87.

Molina O, Ibáñez Z (2013) Politicas de empleo en la UE: respuestas nacionales y Europea a la crisis [Employment policies in the EU: national and European responses to the crisis]. In Anuario IET de Trabajo y relaciones Laborales 2012: Las reformas y el empleo 1: 127-142.

Moreno L (2002) Mediterranean welfare and "superwomen". Consejo Superior de Investigaciones Científicas. Unidad de Políticas Comparadas. Working Paper. n. 02-02. http://www.iesam.csic.es.

Moreno L (2006) The model of social protection in Southern Europe: Enduring characteristics? Consejo Superior de Investigaciones Científicas. Unidad de Políticas Comparadas. Working Paper. n. 06-07. Retrieved from http://www.iesam.csic.es.

OECD (2011) Divided we stand. Why inequality keeps rising. Retrieved from http:// bit.ly/2aIC7IK.

Rhodes M (Ed) (1997) Southern European welfare states: Between crisis and reform. London: Frank Cass.

Pugliese E (Eds) (1996) Una disoccupazione mediterranea. Giovani e mercato del lavoro nel Mezzogiornoe a Napoli [A Mediterranean unemployment. Young people and job market in the South of Naples]. Napoli: Dante e Descartes.

Sánchez A (2009) Crisis y empleo: del mercado de trabajo al modelo económico [Crisis and employment: from the labor market to the economic model]. Trabajo: Revista de las Asociación Estatal de Centros Universitarios de Relaciones Laborales y Ciencias del Trabajo 2: 17-47.

Sapelli G (1996) L'Europa del Sud dopo il 1945. Tradizione e modernità in Portogallo. Spagna. Italia Grecia e Turchia [South Europe after 1945. Tradition and modernity in Portugal. Spain. Italy Greece and Turkey]. Soveria Manelli. Rubettino.

Serrano Pascual A (2007) Activation regimes in Europe: a clustering exercise. In Reshaping Welfare State and Activation Regimes in Europe, A Serrano Pascual, L Magnusson (Eds), 277-319. Peter Lang. Bruselas. 